JESSIE X. FAN AND CATHLEEN D. ZICK

\title{
The Economic Burden of Health Care, Funeral, and Burial Expenditures at the End of Life
}

\begin{abstract}
Research suggests that widows and widowers experience substantial economic vulnerability. Using nationally representative data from the Consumer Expenditure Surveys 1980-2000, we describe pre-widowhood shifts in medical and funeral/burial expenditures and discuss how these changes may affect post-widowhood economic well-being. Our analyses suggest that funeral/burial and medical expenditures, when combined, typically constitute a $\mathbf{6 3 . 1 \%}$ income share for recently widowed households. Discussion focuses on what role consumer educators can play in helping families better manage end-of-life expenditures.
\end{abstract}

In recent years, considerable research has focused on describing the income dynamics of widowed women and men. Yet, we know little about expenditure dynamics near the time of the death and how they may exacerbate or minimize the economic impact of widowhood. Intuitively, one would expect that household spending on funerals and burials would rise with an impending death, although advance planning may minimize some of these expenses. In addition, if the death is preceded by a period of extended illness, then one might anticipate that health care related spending would also rise. The magnitude of the increases in these particular expenditure categories, however, remains generally unknown. In this article, we use data from the 1980 to 2000 panels of the Consumer Expenditure Survey to examine the extent to which household spending in these two specific categories changes near the time of a spouse's death.

Research consistently indicates that widows and widowers experience greater economic vulnerability than do similarly aged married couples (Bound et al. 1991; Holden, Burkhauser, and Feaster 1988; Weir and Willis

Jessie X. Fan is an Associate Professor in the Department of Family and Consumer Studies, University of Utah, Salt Lake City (fan@fcs.utah.edu). Cathleen D. Zick is a Professor of Family and Consumer Studies, University of Utah, Salt Lake City. The research reported in this paper was supported by the National Institute on Aging Grant 1 R03 AG18902-01. The authors are grateful to Kuo-Liang Chang for his excellent research support. This paper was concurrently submitted to $J C A$ and the American Council on Consumer Interests 2003 national conference and presented at their meeting in Atlanta, Georgia. Conference chair Jinkook Lee, Ohio State University, also served as editor of this paper for the journal submission.

The Journal of Consumer Affairs, Vol. 38, No. 1, 2004

ISSN 0022-0078

Copyright 2004 by The American Council on Consumer Interests 
2000; Zick and Smith 1991). For example, one recent study found that in $1997,18 \%$ of widowed women age 65 and older lived in poverty whereas only $4.5 \%$ of married women in this same age group were identified as poor (National Economic Council Interagency Working Group on Social Security 1998). Yet, the process by which widowed individuals come to be poor is not well understood.

Newly widowed individuals' economic well-being may decline for several reasons. When an employed spouse dies, the surviving partner loses the spouse's labor earnings. If a retired spouse dies, the surviving partner may lose the spouse's private pension income (depending on how the couple elected to take the pension benefits), and if the couple was drawing on Social Security at the time of the death, these benefits will also be reduced. Finally, if the couple has had to draw down on assets and/or go into debt to finance rising health care costs and funeral/burial expenses, then this also may contribute to the surviving spouse's decline in economic well-being. Some or all of these factors likely contribute to the postwidowhood decline in economic well-being that has been documented repeatedly in the literature.

To date, much of the research on widowhood and economic well-being has focused on income changes near widowhood (Bound et al. 1991; Holden et al. 1988; Weir and Willis 2000; Zick and Smith 1991). This current paper is part of an emerging effort (McGarry and Schoeni 2001; Zick, Fan, and Chang 2003) to examine how pre-widowhood changes in expenditure patterns may contribute to post-widowhood changes in economic well-being.

Our exploratory analysis focuses on the expenditure categories of medical care and burial and funeral expenditures. Intuitively, these would appear to be the areas where an impending death is most likely to trigger a change in expenditures. ${ }^{1}$ Expenditures on housing, utilities, food, clothing, and transportation are likely to be relatively stable in the months surrounding a husband's or wife's death. But, as a spouse's health declines, the couple may increase their spending on such things as medical care and funeral/ burial planning. In this paper we will investigate the extent to which shifts occur in these expenditure categories and we will speculate on what consequences such spending is likely to have for the subsequent well-being of the surviving spouse. 


\section{LITERATURE REVIEW}

The existing literature on health care spending at the end of life is substantial although scholars working in this area tend to emphasize total health care spending and/or expenditures covered by Medicare, Medicaid, and/or private insurance (Garber, MaCurdy, and McClellan 1998; Levinsky et al. 2001; Long et al. 1984; Lubitz and Riley 1993) rather than outof-pocket expenditures. Our focus is on the much smaller literatures devoted to out-of-pocket health care and funeral/burial expenditures. We review the literature on out-of-pocket health care spending first, followed by the literature on funeral/burial expenditures.

\section{Out-of-Pocket Medical Care Expenditures}

In 1996, \$907.2 billion were spent on health care in the United States. Third party payments covered only $81 \%$ of that total with the remaining $\$ 172.4$ billion being paid out-of-pocket by consumers (U.S. Bureau of the Census 1998). Research has shown that these out-of-pocket health care expenditures increase with age (Acs and Sabelhaus 1995; Cutler and Meara 1998; Hitschler 1993; Rubin and Koelln 1993) and chronic disease status (Mueller, Schur, and O'Connell 1997). Could these increases in outof-pocket health care expenditures associated with age and chronic disease status be a factor that contributes to the increased risk that a newly widowed individual will experience a substantial decline in needs-adjusted income?

McGarry and Schoeni (2001) and Zick, Fan, and Chang (2003) have undertaken the most comprehensive analyses of pre-widowhood out-ofpocket medical expenditures to date. McGarry and Schoeni (2001) use data from the Asset and Health Dynamics (AHEAD) study to compare the out-of-pocket medical expenditures for households where a spouse dies between interviewing waves one and two $(N=271)$ with the out-of-pocket medical expenditures for an otherwise comparable group of continuously married households $(N=3559)$. They find that out-of-pocket health care expenditures are almost twice as high for about-to-be widowed households compared to their continuously married counterparts. Expenditures are particularly elevated for prescription drugs, nursing homes, and "special services." From their analyses, McGarry and Schoeni (2001) conclude that out-of-pocket medical expenditures in the last year of life are typically large and these expenditures account for approximately $25 \%$ of the in- 
crease in post-widowhood poverty that we observe among older widows and widowers (i.e., individuals widowed after age 69).

Zick, Fan, and Chang (2003) use data from the Medical Expenditure Panel Survey (MEPS) to examine out-of-pocket health care expenditures in an age-heterogeneous sample of about-to-be widowed households compared to the expenditures of similarly aged, continuously married couples. Their analyses, like those of McGarry and Schoeni (2001), reveal that outof-pocket medical expenditures are significantly higher for the about-tobe-widowed group than for the continuously married group. They find that the differences are particularly large when the soon-to-be deceased is under age 70 or if he or she is not eligible for Medicare.

\section{Funeral and Burial Expenditures}

The literature on funeral expenditures is very sparse. The National Funeral Directors Association (NFDA) conducts a funeral price survey each year. In the 2001 survey, they found that the average price (excluding cemetery charges) was $\$ 6,130$ (NFDA 2001). The American Association of Retired Persons (AARP) (2002) notes that funeral and burial expenditures, when summed together, often exceed $\$ 10,000$.

To the extent that individuals plan their funerals and burials in advance (i.e., they comparison shop and identify their preferred funeral/burial arrangements long before there is the time pressure of immediate need), expenses related to these purchases may be minimized. Yet, we know little about the extent to which consumers engage in such activities. In a funeral cost survey of 162 next-of-kin in Kansas City, MO, Bern-Klug, Ekerdt, and Wilkinson (1999) found that $42 \%$ of decedents had "finalized arrangements" with a funeral director, cemetarian, or memorial society before the death. ${ }^{2}$ In a related paper, Bern-Klug, DeViney, and Ekerdt (2001) use the same survey data to examine total funeral-related expenditures as a function of (a) having a pre-need funeral home contract, and (b) type of body disposition. They find that those with pre-need contracts spent approximately $\$ 1,400$ less than those without such contracts. Thus, advance planning may serve to reduce overall expenditures.

There is considerable price variation in the funeral and burial markets. For example, Davis and Knestout (1997) report that in a 1996 survey of more than 100 funeral homes in the Houston area, the cost for the same basic funeral ranged from $\$ 1,495$ to $\$ 9,910$. The Federal Trade Commission's 1984 Funeral Rule requires that funeral homes provide price lists to help families assess the range of options and the associated prices. Those 
families who engage in planning long before the death essentially have more time to comparison shop, and such search behavior could lower the overall expenditures for a funeral and/or burial.

Unfortunately, many families do not plan funerals and/or burial arrangements in advance. This means that typically funeral and burial decisions are made under considerable time and emotional pressure that may reduce search. In addition, cultural and/or religious constraints may narrow the range of options. Thus, we would generally expect to find that funeral and burial expenses are typically large near the time of the death.

\section{METHODS}

Our investigation is purely descriptive. We draw on both the neoclassical economics framework and the life course framework to inform the specification of our multivariate analyses. Proponents of the neoclassical economics framework argue that household expenditures are influenced by income, prices, and preferences. While predictions about the roles that income and prices play are clear (i.e., increases in income are hypothesized to lead to increased consumption of all normal goods including health care and funerals/burials), the economic model provides less guidance regarding how preferences may alter expenditures. To gain a better understanding of the role that preference shifters may play, we turn to the life course framework. Proponents of this framework argue that families' social and behavioral responses to life events (e.g., an impending death) are dependent upon the interaction of age, period, and cohort effects (Bengtson and Allen 1993). Thus, our preference measures will include variables that capture these three dimensions of family life.

Our goal in the multivariate analysis is to identify what role impending widowhood plays in households' health care and funeral/burial expenditures once we control for income, prices (as approximated by regional variables), and a somewhat standard set of life course sociodemographic covariates. We focus on these expenditure categories because we believe they are the most likely to shift in response to an impending death.

The data for our study come from the interview portion of the 1980 to 2000 Consumer Expenditure (CE) Surveys (U.S. Bureau of Labor Statistics and Department of Labor 1980-2000). The CE Survey is the most comprehensive source of detailed information on family expenditure, income, and other socioeconomic and demographic characteristics of the U.S. non-institutionalized civilian population. The CE Survey is conducted quarterly with rotating panels of approximately 5,000 families, 
who are interviewed for five consecutive quarters. One-fifth of the sample is new each quarter. The unit of analysis in the CE Survey is the consumer unit (CU), which is defined as all members of a household related by blood, marriage, adoption or other legal arrangements; or as someone living alone or sharing quarters with others but financially independent; or as two or more persons who pool income and make joint expenditures (U.S. Bureau of Labor Statistics and Department of Labor 1980-2000).

The death of a spouse is an extremely rare event for young married persons. Thus, the sample used in this study is restricted to respondents age 40 or above at the beginning of their participation in the survey. Two groups of respondents age 40 and above are included in the sample: (1) those who report they are married to the same person in all interviews and for whom information on both spouses is available in the data (i.e., the continuously married), and (2) those who report subsequent to the first interview that their marital status has changed from married to widowed with spousal information before the widowhood event available in the data (i.e., the about-to-be widowed). In addition, because the estimates in expenditure studies involving health care expenditures are very sensitive to outliers, CUs with real out-of-pocket medical expenditures outside 15 standard deviations from the sample mean are excluded (about $2 \%$ of the sample). The final sample size for the continuously married group is 25,782 . The sample size for the about-to-be widowed group is 137 . A separate sample of married CUs with both spouses 40 or older at the first interview who did not participate in all four interviews is also selected for the purpose of estimating sample selection biases due to nonparticipation in subsequent interviews. The size for this sample is 4,928 .

Given the small sample size for the about-to-be-widowed group and given our focus on expenditures, we elect to keep both complete income reporters and incomplete income reporters in our sample. We do control for income reporting status in all of our multivariate analyses. Our estimates of income shares, however, are limited to the sample of complete income reporters. It should be noted that even with complete income reporters, it is possible that not all sources of income are included (Garner and Blanciforti 1994). This is likely to result in an underestimation of before-tax income, thus leading to an upward bias of our income share estimates. On the other hand, in the CE, after-tax income (which we use) is computed by subtracting taxes from before-tax income. Because errors involved in tax data (i.e., refusal or reporting zero if getting a refund) can result in an underestimation of tax, after-tax income is likely to be overestimated. This leads to a downward bias of our income share estimates. Thus the overall effect is unclear. 
The about-to-be widowed sample is older than the continuously married sample and thus we adjust the weights so the final weighted age distribution for the continuously married group is the same as the age distribution of the about-to-be-widowed group. ${ }^{3}$ All expenditure and demographic statistics reported here are weighted by these age-adjusted weights. Further, because our sample covers a span of 21 years, the Consumer Price Index (CPI) is used to adjust all expenditure figures to 2001 constant dollars.

We investigate out-of-pocket expenditures for (1) medical care, including health insurance, prescription drugs, emergency room visits, hospital visits, office-based visits, dental, nursing home, ${ }^{4}$ home health care, and all other health care; and (2) funerals/burials, including funeral, burial or cremation expenses, and the purchase and upkeep of cemetery lots or vaults. It should be noted that in the CE Survey, the medical expenditures are collected in a net outlay (i.e., all payments minus all reimbursements for that quarter) format. For our purpose, this data format is not advantageous because some expenses prior to the death may not be paid until several months after the death. If the payment is made in a quarter subsequent to the one where the death was reported, then it is excluded from our measure of medical care expenditures, making our estimates conservative.

Both medical and funeral/burial expenditures are measured at the household rather than the individual level. This means that some expenditures may be for someone other than the about-to-be-deceased spouse. But by including a comparison group of continuously married couples in our analyses, we are able to ascertain what the marginal increase in medical and funeral/burial expenditures is that can be attributed to the impending death.

The expenditure data are re-centered by the interview where the respondent first reported his or her marital status as widowed, as we are interested in medical and funeral/burial expenditures incurred in the months immediately surrounding the death. We designate this interview as the "reference interview." For comparison purposes, we randomly assign a reference interview to the households in the continuously married sample using the reference interview distribution of the about-to-be-widowed sample. For the about-to-be-widowed group, we designate the spouse who died during the panel as the "reference spouse." For the continuously married sample, we randomly assign either widower or widow status using the gender distribution of the about-to-be-widowed sample to create a pseudo reference spouse. If a widower status is randomly assigned to a continuously married household, then the reference spouse is the wife, whereas the reference spouse is the husband if a widow status is assigned.

The expenditure variables we examine are measured as the sum of two 
quarterly expenditures reported in (a) the interview prior to the reference interview and (b) the reference interview. The total time period covered by these two interviews is exactly six months. In order to get an overall picture of out-of-pocket expenditures for these two categories and the impact of these out-of-pocket expenditures on the overall family budget and family economic status, we focus on the out-of-pocket expenditures, their budget shares, and their income shares in this study. Descriptive statistics on the sample characteristics and their expenditure patterns are first computed for both groups. Next, we control for income, prices, and basic lifecourse characteristics to see if the about-to-be widowed group spends more compared to the continuously married group, ceteris paribus.

In the multivariate analyses, income is measured as the household's reported after-tax annual income. For incomplete income reporters, income is set to be zero. A dummy variable that measures whether or not the household was a complete income reporter is included to capture the effect of being an incomplete income reporter. We do not have direct information on health care and funeral/burial prices in this data set. As a second-best solution, we use region of residence and presence or absence of health insurance of the reference spouse to control for price variations. Life course measures of household preferences include age, race, education, and employment status of the reference spouse, along with family size and interview year. ${ }^{5}$

Since health insurance information is available starting in 1988, the coverage variables are constructed for the years before 1988. For the private insurance variable, we code a $\mathrm{CU}$ as having private insurance coverage if there is any payment on any of the private insurance categories. For the Medicare variable, a CU is coded as having Medicare if the reference spouse is 65 or older. For the Medicaid variable, a CU is coded as having Medicaid if the CU's income is below the poverty threshold. Poverty status is constructed using family income and composition information and federal poverty guidelines for each year. Finally, family size for the aboutto-be widowed group is adjusted by assuming that the reference spouse died at the midpoint between the two interviews since we do not have information on the exact date of death. Measurements of all other variables are self-explanatory.

The error terms of these expenditure categories are likely to be correlated. As a consequence, a Seemingly Unrelated Regression (SUR) estimation method is used and the equations for the two categories are simultaneously fitted. We also correct for sample selection bias due to non-participation in all four quarters of interviews. In addition, a two-stage Tobit is used to correct for the limited dependent variable problem on the 
funeral/burial expenditure category (Fan 1997; Greene 1997; Maddala 1983). Four models are estimated for each set of equations: (1) using the about-to-be-widowed sample only, (2) using the continuously married sample only, (3) using pooled data with a widowhood dummy and interaction terms of all variables with the widowhood dummy (full model), and (4) using pooled data without the widowhood dummy and interaction terms (reduced model).

\section{RESULTS}

Table 1 presents the weighted demographic profile of the sample. The about-to-be widowed and continuously married groups are quite similar on most dimensions. The exceptions are after-tax household income, race,

\section{TABLE 1}

Age-Weighted Sociodemographic Profile of the Sample ${ }^{a}$

\begin{tabular}{lcc}
\hline & $\begin{array}{c}\text { Continuously } \\
\text { Married } \\
(N=25,782)\end{array}$ & $\begin{array}{c}\text { About-to-be Widowed } \\
(N=137)\end{array}$ \\
Variable & 65.7 & 68.3 \\
\hline Mean age of reference spouse (standard deviation) & $(3.43)$ & $(10.8)$ \\
& 2.51 & 2.33 \\
Mean family size (standard deviation) & $(0.33)$ & $(1.08)$ \\
& & \\
After-tax household income for complete income & 50,326 & 28,508 \\
reporters (standard deviation) & $(39,541)$ & $(20,443)$ \\
& & \\
Race/ethnicity of reference spouse (\%): & 90.2 & 83.7 \\
White and others & 5.8 & 14.3 \\
Black & 4.0 & 2.0 \\
Hispanic & & \\
Education of reference spouse (\%): & 75.7 & 78.4 \\
High school or less & 24.3 & 21.6 \\
More than high school & 41.9 & 28.7 \\
Reference spouse employed (\%) & & \\
Region of residence (\%): & 23.5 & 23.7 \\
Urban South & 60.0 & 64.3 \\
Urban Non-South & 16.5 & 12.0 \\
Rural & & \\
Health insurance (\%): & 85.7 & 82.8 \\
Has private insurance & 63.6 & 64.1 \\
Has Medicare & 10.5 & 12.8 \\
Has Medicaid & 14.8 & 14.0 \\
Incomplete income reporters (\%) & 11.4 & 10.3 \\
Year (1-21) (standard deviation) & $(1.83)$ & $(5.53)$ \\
\hline & &
\end{tabular}

${ }^{a}$ Percentages may not sum to $100 \%$ because of rounding. 
and employment status. On average, compared to their continuously married counterparts, the about-to-be widowed group has a lower average income, a result consistent with previous work that has found an inverse relationship between income and the risk of mortality (Daley, Duncan, Kaplan, and Lynch 1998; McDonough, Duncan, Williams, and House 1997). In addition, a higher proportion of the about-to-be widowed group is minority, compared to the continuously married group, and the reference spouse in the about-to-be widowed group is less likely to be employed than the reference spouse in the continuously married group.

The lower levels of economic well-being and labor force participation among the about-to-be widowed may be the result of one or both spouses cutting back on their labor supply because of the to-be-deceased spouse's declining health. The difference in the racial composition may reflect the relatively higher mortality risk faced by black individuals (National Center for Health Statistics 2002). Regardless of the reasons for these differences, they do suggest that controlling for race, income, and labor force participation may be particularly important in multivariate analyses if we are to get a clear assessment of the ceteris paribus impact of impending widowhood.

Table 2 presents means and distributional information for the two expenditure categories as well as their total. Out-of-pocket expenditures on medical care are only slightly higher for the about-to-be-widowed group than the continuously married group. Table 3 shows that among the subcategories of medical care, out-of-pocket expenditures on health insurance, dental care, and other health care are lower for the about-to-be widowed group, ${ }^{6}$ while expenditures on prescription drugs, emergency room visits, hospital visits, office-based visits, nursing home, and home care are higher. The differences in total out-of-pocket medical expenditures between these two groups are lower than those found in Zick et al. (2003) using MEPS data, and those found in McGarry and Schoeni (2001) using AHEAD data. This difference may arise because the CE Survey measures health care expenditures differently from MEPS and AHEAD. Specifically, MEPS and AHEAD use an event-specific approach to measuring health care expenditures while the CE Survey uses a net outlay per quarter approach. As we noted earlier, if there is a lag between obtaining medical services and paying for such services, then the CE Survey may undercount overall out-of-pocket expenditures related to an impending death if the bills are not paid during the two panel periods used here.

Turning back to Table 2, the mean funeral/burial expenditures for the about-to-be widowed group is $\$ 3,502$, with a non-zero mean of $\$ 4,870$, 
TABLE 2

Age-Weighted Six-Month Expenditures on Selected Categories by Group: Continuously Married (M) and About-to-be Widowed (W) ${ }^{a}$

\begin{tabular}{|c|c|c|c|c|c|c|c|}
\hline & & \multicolumn{2}{|c|}{$\begin{array}{c}\text { Total } \\
\text { Medical } \\
\text { Expenditures } \\
\end{array}$} & \multicolumn{2}{|c|}{$\begin{array}{c}\text { Total } \\
\text { Funeral/Burial } \\
\text { Expenditures } \\
\end{array}$} & \multicolumn{2}{|c|}{$\begin{array}{c}\text { Medical and } \\
\text { Funeral/Burial } \\
\text { Combined }\end{array}$} \\
\hline & & $\mathbf{M}$ & W & $\mathbf{M}$ & W & $\mathbf{M}$ & W \\
\hline \multirow{7}{*}{$\begin{array}{r}\text { Expenditure in } \\
2001 \text { dollars }\end{array}$} & Mean & 1,595 & 1,597 & 98 & 3,502 & 1,693 & 5,099 \\
\hline & Median & 1,255 & 1,229 & 0 & 2,557 & 1,300 & 4,269 \\
\hline & $75 \%$ & 2,173 & 2,176 & 0 & 6,029 & 2,245 & 8,060 \\
\hline & $90 \%$ & 3,323 & 3,425 & 33 & 7,920 & 3,539 & 10,579 \\
\hline & $95 \%$ & 4,224 & 3,985 & 163 & 9,129 & 4,527 & 12,596 \\
\hline & $\%$ Non-zero & 98 & 95 & 13 & 72 & 98 & 98 \\
\hline & Non-zero mean & 1,628 & 1,680 & 767 & 4,870 & 1,728 & 5,177 \\
\hline \multirow[t]{5}{*}{ Budget share (\%) } & Mean & 11.1 & 10.2 & 0.5 & 18.9 & 11.7 & 29.1 \\
\hline & Median & 8.5 & 8.4 & 0 & 17.0 & 8.9 & 27.6 \\
\hline & $75 \%$ & 15.7 & 15.2 & 0 & 33.9 & 16.5 & 42.6 \\
\hline & $90 \%$ & 24.4 & 21.9 & 0.2 & 43.6 & 25.7 & 54.8 \\
\hline & $95 \%$ & 30.6 & 27.2 & 1.0 & 47.6 & 32.6 & 62.9 \\
\hline \multirow[t]{5}{*}{ Income share $(\%)$} & Mean & 33.7 & 14.9 & 1.1 & 47.4 & 50.8 & 62.3 \\
\hline & Median & 8.2 & 9.4 & 0 & 25.8 & 8.5 & 37.0 \\
\hline & $75 \%$ & 17.0 & 20.6 & 0 & 54.7 & 17.7 & 80.3 \\
\hline & $90 \%$ & 29.0 & 36.1 & 0.2 & 96.3 & 31.6 & 128.1 \\
\hline & $95 \%$ & 43.3 & 52.3 & 1.1 & 168.3 & 46.5 & 196.6 \\
\hline
\end{tabular}

${ }^{a}$ The whole sample is used for expenditures in dollar and budget shares calculations. The sample size for the continuously married group is 25,782 . The sample size for the about-to-be widowed group is 137 . For the income shares calculations, only complete income reporters are included. The sample size for the continuously married group is 21,266 . The sample size for the about-to-be widowed group is 113 .

lower than the estimate of $\$ 6,130$ from NFDA for the average funeral price (NFDA 2001). This difference is not surprising because some prepayment arrangements may have been made. The fact that $13 \%$ of the continuously married couples spent an average of $\$ 767$ on funeral-related expenditures supports this notion. At the high end of the distribution, the 95th percentile figure on funeral/burial expenditures is $\$ 9,129$, close to the $\$ 10,000$ figure reported by AARP (2002).

Table 2 also shows the distributional data on budget and income shares for health care and funeral/burial expenditures. Budget and income share statistics provide us with a closer look at the impact of these expenditures on family economic well-being. While the budget share for medical expenses is lower for the about-to-be-widowed group than the continuously married group, the budget share for funeral expenditures is $18.9 \%$ for the 
TABLE 3

Age-Weighted Six-Month Detailed Medical Expenditures in 2001 Constant Dollars by Group: Continuously Married (M) and About-to-be Widowed (W)

\begin{tabular}{|c|c|c|c|c|c|c|c|}
\hline Expenditure Category & & Mean & Median & $\begin{array}{c}\text { 75th } \\
\text { Percentile }\end{array}$ & $\begin{array}{c}\text { 95th } \\
\text { Percentile }\end{array}$ & $\begin{array}{c}\text { Percent } \\
\text { Non-Zero }\end{array}$ & $\begin{array}{c}\text { Non-Zero } \\
\text { Mean }\end{array}$ \\
\hline \multirow[t]{2}{*}{ Health insurance } & $\mathbf{M}$ & 783 & 579 & 1,104 & 2,276 & 87 & 900 \\
\hline & W & 559 & 407 & 794 & 1,613 & 88 & 632 \\
\hline \multirow[t]{2}{*}{ Prescription drugs } & $\mathbf{M}$ & 277 & 113 & 364 & 1,131 & 79 & 351 \\
\hline & W & 319 & 159 & 454 & 1,228 & 79 & 404 \\
\hline \multirow[t]{2}{*}{ Emergency room visits } & $\mathbf{M}$ & 7 & 0 & 0 & 0 & 4 & 176 \\
\hline & W & 24 & 0 & 0 & 109 & 11 & 226 \\
\hline \multirow[t]{2}{*}{ Hospital visits } & $\mathbf{M}$ & 53 & $\mathbf{0}$ & 0 & 289 & 13 & 422 \\
\hline & W & 196 & $\mathbf{0}$ & 7 & 833 & 25 & 778 \\
\hline \multirow[t]{2}{*}{ Office-based visits } & $\mathbf{M}$ & 171 & 45 & 197 & 784 & 64 & 269 \\
\hline & W & 198 & 46 & 226 & 794 & 65 & 303 \\
\hline \multirow[t]{2}{*}{ Dental } & $\mathbf{M}$ & 170 & 0 & 123 & 898 & 42 & 406 \\
\hline & w & 101 & 0 & 33 & 361 & 26 & 391 \\
\hline \multirow[t]{2}{*}{ Nursing home } & $\mathbf{M}$ & 5 & 0 & 0 & 0 & 0.5 & 875 \\
\hline & W & 32 & 0 & 0 & 0 & 0.8 & 4,118 \\
\hline \multirow[t]{2}{*}{ Home care } & $\mathbf{M}$ & 11 & 0 & 0 & 0 & 0.9 & 1,198 \\
\hline & W & 63 & 0 & 0 & 0 & 4.5 & 1,402 \\
\hline \multirow[t]{2}{*}{ All other health care } & $\mathbf{M}$ & 118 & $\mathbf{0}$ & 124 & 529 & 43 & 274 \\
\hline & w & 105 & 0 & 73 & 478 & 44 & 236 \\
\hline
\end{tabular}

${ }^{a}$ Note that all expenditures are adjusted by the overall CPI.

about-to-be-widowed group on average, compared to $0.5 \%$ for the continuously married group. At the extreme end of the distribution, a CU can spend about two-thirds of its budget on medical care and funeral expenses combined, indicating the burden of these two expenses can be very large for some families. The figures are even more dramatic when income shares are investigated. On average, a CU in the about-to-be widowed group spends slightly less than half of its total after-tax income on funeral/burial arrangements. At the extreme end of the distribution, the income share for funeral expenditures reaches $96.3 \%$ for the 90 th percentile and $168.3 \%$ for the 95 th percentile, a clear indication that savings are used or money is borrowed for this expense. About 15\% of the households in the about-to-be widowed group cannot possibly meet their medical and funeral expenses using only current income. They must either use their savings or borrow money to cover these combined expenses.

The next step is to estimate descriptive, multivariate regressions for these two expenditure categories to see if the differences observed at the descriptive level still exist after controlling for sociodemographic factors. The independent variables in these descriptive regressions include the eco- 
nomic and life course characteristics identified in Table 1. Table 4 reports results from multivariate regressions for total out-of-pocket expenditures on medical care and funerals/burials, estimated for the two groups separately.

In order to assess the magnitude of the differences in expenditures between these two groups, holding other things equal, the expenditures were predicted using the two sets of regression equations for observations in the about-to-be widowed group. The means of the predictions are reported in Table 5. To test the statistical significance of this difference, F-tests were

TABLE 4

Age-Weighted Parameter Estimates of Regression Coefficients for Out-of-Pocket Expenditures on Medical Care and Funerals/Burials (t-ratios in parentheses)

\begin{tabular}{|c|c|c|c|c|}
\hline \multirow[t]{2}{*}{ Independent Variables } & \multicolumn{2}{|c|}{$\begin{array}{l}\text { Total Expenditure } \\
\text { on Medical Care }\end{array}$} & \multicolumn{2}{|c|}{$\begin{array}{l}\text { Total Expenditure } \\
\text { on Funerals/Burials }\end{array}$} \\
\hline & $\begin{array}{l}\text { Continuously } \\
\text { married }\end{array}$ & $\begin{array}{l}\text { About-to-be } \\
\text { widowed }\end{array}$ & $\begin{array}{l}\text { Continuously } \\
\text { married }\end{array}$ & $\begin{array}{l}\text { About-to-be } \\
\text { widowed }\end{array}$ \\
\hline Intercept & $\begin{array}{l}-335.3 \\
(-3.37)^{* * *}\end{array}$ & $\begin{array}{r}-1995.9 \\
(-1.42)\end{array}$ & $\begin{array}{r}-1407.5 \\
(-0.54)\end{array}$ & $\begin{array}{l}3062.3 \\
(0.88)\end{array}$ \\
\hline Age of reference spouse & $\begin{array}{l}16.3 \\
(14.55)^{* * *}\end{array}$ & $\begin{array}{l}31.7 \\
(2.02)^{* *}\end{array}$ & $\begin{array}{l}4.1 \\
(0.86)\end{array}$ & $\begin{array}{l}-9.3 \\
(-0.22)\end{array}$ \\
\hline Family size & $\begin{array}{l}41.9 \\
(4.87)^{* * *}\end{array}$ & $\begin{array}{l}-16.8 \\
(-0.12)\end{array}$ & $\begin{array}{l}-6.0 \\
(-0.83)\end{array}$ & $\begin{array}{r}463.8 \\
(1.19)\end{array}$ \\
\hline $\begin{array}{l}\text { After tax household income } \\
\quad \text { (in } \$ 10,000 \text { ) }\end{array}$ & $\begin{array}{l}13.2 \\
(4.41)^{* * *}\end{array}$ & $\begin{array}{l}49.1 \\
(0.64)\end{array}$ & $\begin{array}{l}-7.63 \\
(-1.18)\end{array}$ & $\begin{array}{l}431.2 \\
(1.73)^{*}\end{array}$ \\
\hline $\begin{array}{l}\text { Incomplete income reporter } \\
\qquad(1=\text { yes })\end{array}$ & $\begin{array}{l}60.0 \\
(2.29)^{* *}\end{array}$ & $\begin{array}{l}369.7 \\
(0.83)\end{array}$ & $\begin{array}{l}-172.9 \\
(-0.70)\end{array}$ & $\begin{array}{r}1847.0 \\
(1.20)\end{array}$ \\
\hline $\begin{array}{l}\text { Reference spouse employed } \\
\qquad(1=\text { yes })\end{array}$ & $\begin{array}{l}29.6 \\
(1.46)\end{array}$ & $\begin{array}{r}-523.6 \\
(-1.64)\end{array}$ & $\begin{array}{l}-17.3 \\
(-0.50)\end{array}$ & $\begin{array}{r}1549.6 \\
(1.49)\end{array}$ \\
\hline $\begin{array}{l}\text { Reference spouse is African } \\
\text { American }(1=\text { yes })^{a}\end{array}$ & $\begin{array}{l}-415.4 \\
(-11.68) * * *\end{array}$ & $\begin{array}{l}-354.3 \\
(-0.86)\end{array}$ & $\begin{array}{l}-48.6 \\
(-0.23)\end{array}$ & $\begin{array}{l}1318.6 \\
(0.87)\end{array}$ \\
\hline $\begin{array}{l}\text { Reference spouse is Hispanic } \\
\quad(1=\text { yes })^{a}\end{array}$ & $\begin{array}{l}-390.7 \\
(-9.19)^{* * *}\end{array}$ & $\begin{array}{l}-958.9 \\
(-0.88)\end{array}$ & $\begin{array}{l}-4.1 \\
(-0.14)\end{array}$ & $\begin{array}{r}-2449.1 \\
(-0.92)\end{array}$ \\
\hline $\begin{array}{c}\text { Reference spouse has post-hig } \\
\text { school education }(1=\text { yes })\end{array}$ & $\begin{array}{l}172.3 \\
(8.84)^{* * *}\end{array}$ & $\begin{array}{l}283.5 \\
(0.88)\end{array}$ & $\begin{array}{l}-79.1 \\
(-0.71)\end{array}$ & $\begin{array}{l}-676.6 \\
(-0.86)\end{array}$ \\
\hline $\begin{array}{l}\text { Couple resides in urban South } \\
(1=\text { yes })^{b}\end{array}$ & $\begin{array}{l}272.4 \\
(13.83) * * *\end{array}$ & $\begin{array}{l}258.8 \\
(0.80)\end{array}$ & $\begin{array}{l}127.4 \\
(0.64)\end{array}$ & $\begin{array}{l}18.0 \\
(0.02)\end{array}$ \\
\hline
\end{tabular}


TABLE 4 (continued)

Age-Weighted Parameter Estimates of Regression Coefficients for Out-of-Pocket Expenditures on Medical Care and Funerals/Burials (t-ratios in parentheses)

\begin{tabular}{|c|c|c|c|c|}
\hline \multirow[t]{2}{*}{ Independent Variables } & \multicolumn{2}{|c|}{$\begin{array}{l}\text { Total Expenditure } \\
\text { on Medical Care }\end{array}$} & \multicolumn{2}{|c|}{$\begin{array}{c}\text { Total Expenditure } \\
\text { on Funerals/Burials }\end{array}$} \\
\hline & $\begin{array}{l}\text { Continuously } \\
\text { married }\end{array}$ & $\begin{array}{l}\text { About-to-be } \\
\text { widowed }\end{array}$ & $\begin{array}{l}\text { Continuously } \\
\text { married }\end{array}$ & $\begin{array}{l}\text { About-to-be } \\
\text { widowed }\end{array}$ \\
\hline \multicolumn{5}{|l|}{ Couple resides in rural areas } \\
\hline$(1=\text { yes })^{b}$ & $\begin{array}{l}133.0 \\
(5.88)^{* * *}\end{array}$ & $\begin{array}{l}312.4 \\
(0.74)\end{array}$ & $\begin{array}{l}56.8 \\
(0.37)\end{array}$ & $\begin{array}{l}362.2 \\
(0.35)^{* * *}\end{array}$ \\
\hline \multicolumn{5}{|c|}{ Reference spouse has private health } \\
\hline insurance $(1=$ yes $)$ & $\begin{array}{l}655.9 \\
(27.04)^{* * *}\end{array}$ & $\begin{array}{l}1280.5 \\
\quad(3.41)^{* * *}\end{array}$ & $\begin{array}{l}235.2 \\
(0.67)\end{array}$ & $\begin{array}{r}-1336.1 \\
(-1.00)\end{array}$ \\
\hline \multicolumn{5}{|l|}{ Reference spouse has Medicare } \\
\hline$(1=$ yes $)$ & $\begin{array}{l}275.7 \\
(11.34)^{* * *}\end{array}$ & $\begin{array}{l}-861.7 \\
(-2.53)^{* *}\end{array}$ & $\begin{array}{l}36.4 \\
(0.67)\end{array}$ & $\begin{array}{l}702.1 \\
(0.54)\end{array}$ \\
\hline \multicolumn{5}{|l|}{ Reference spouse has Medicaid } \\
\hline$(1=$ yes $)$ & $\begin{array}{l}-180.7 \\
(-6.25)^{* * *}\end{array}$ & $\begin{array}{l}-416.6 \\
(-0.99)\end{array}$ & $\begin{array}{l}-5.8 \\
(-0.04)\end{array}$ & $\begin{array}{l}-691.1 \\
(-0.66)\end{array}$ \\
\hline \multicolumn{5}{|l|}{ Year (coded from 1-20 with } \\
\hline $1=1980$ and $21=2000$ ) & $\begin{array}{l}15.1 \\
(9.89)^{* * *}\end{array}$ & $\begin{array}{l}30.9 \\
(1.26)\end{array}$ & $\begin{array}{l}0.3 \\
(0.19)\end{array}$ & $\begin{array}{l}99.9 \\
(1.31)\end{array}$ \\
\hline \multicolumn{5}{|c|}{ Lambda correction for having data } \\
\hline for all four quarters & $\begin{array}{l}-1057.8 \\
(-8.31)^{* * *}\end{array}$ & $\begin{array}{l}1970.0 \\
(1.15)\end{array}$ & $\begin{array}{l}-186.4 \\
(-2.35)^{* * *}\end{array}$ & $\begin{array}{l}2090.6 \\
(0.50)\end{array}$ \\
\hline $\begin{array}{l}\text { Correction for limited depend } \\
\text { variable }\end{array}$ & N.A. & N.A. & $\begin{array}{c}918.6 \\
(0.55)\end{array}$ & $\begin{array}{l}-13095.8 \\
\quad(-2.73)^{* * *}\end{array}$ \\
\hline Adjusted $\mathrm{R}^{2}$ & 0.12 & 0.11 & 0.01 & 0.06 \\
\hline
\end{tabular}

${ }^{a}$ The omitted group in this series of dummy variables is those households where the reference spouse is white.

${ }^{b}$ The omitted group in this series of dummy variables is those households living in the urban Northeast, Midwest, or West.

${ }^{*} \mathrm{p}<.10 ;{ }^{* *} \mathrm{p}<.05 ;{ }^{* * *} \mathrm{p}<.01$

\section{TABLE 5}

Predicted Six-Month Expenditures on Selected Categories by Group:

Continuously Married $(M)$ and About-to-be Widowed $(W)^{a}$



${ }^{a}$ The about-to-be widowed group $(n=137)$ is used for the simulation. 
conducted using estimates from the full models and reduced models (results not presented but available upon request).

In general, the equation fit is better for the health care expenditure category than for the funeral/burial expenditure category. For the health care expenditure equation, more explanatory variables are significant at conventional levels in the continuously married group equation than the about-to-be widowed equation, probably due to sample size differentials. ${ }^{7}$ Table 5 reveals that about-to-be widowed households spend significantly more money on both medical care and funerals/burials. The average sixmonth predicted medical expenditures are quite close: $\$ 1,597$ for the about-to-be widowed group and $\$ 1,518$ for the otherwise identical continuously married group - a difference of about $5 \%$. The estimate of this difference is lower than those obtained in the two previous studies that have examined pre-widowhood medical expenditures (McGarry and Schoeni 2001; Zick et al. 2003). The relatively small difference between the two groups may be a function of the lag between the receipt of health care services and the payment for those services. As expected, funeral/burial expenditures are much higher for the about-to-be widowed group $(\$ 3,502$ on average) than for the continuously married group ( $\$ 113$ on average), ceteris paribus. These differences are statistically significant at $90 \%$ level for the health care expenditure category and at $99 \%$ level for the funeral/ burial expenditure category.

Other variables that affect out-of-pocket expenditures on health care include age, family size, income, income reporting status, ethnicity/race, education, region of residence, health insurance, and year of interview. Not surprisingly, older individuals spend more out-of-pocket on health care and funerals/burials than do younger individuals, and the effect is larger for the about-to-be widowed group than for the continuously married group. In addition, health insurance coverage has a different effect on health care expenditures for the two groups. For the about-to-be widowed group, those who carried private insurance spent an average of $\$ 1,280$ more than those who did not carry private health insurance. Those who have Medicare or Medicaid, however, spend less than those who do not. In contrast, while those in the continuously married group who have private insurance also spend more than those who do not have private health insurance, the difference is only $\$ 656$ on average. The marginal effect of having Medicare is positive for the continuously married group, while the marginal effect of having Medicaid is negative, other things being equal.

The rest of the demographic variables are only significant in the continuously married equation. Family size and after-tax income are positively associated with increases in out-of-pocket medical expenditures. Medical 
expenditures are higher for households that are incomplete income reporters, those with post-high school education, and those residing in the urban south or rural areas, compared with those that are complete income reporters, those with a high school education or less, or those residing in urban, non-southern areas. Minority households spend less on medical care compared to white households. Finally, the coefficients on the trend variable (Year) suggest that from 1980 to 2000, expenditures for medical care increased in real terms over this 20 -year period. This trend may be a function of a combination of higher-than-average relative inflation in medical care prices and possibly greater demand for medical care services as treatment and drug options have expanded over time.

For the funeral/burial expenditure equations, no demographic variable can explain the variance among the continuously married group. A combined model (not shown, but available upon request) shows that the widowhood event is the single most important variable in predicting expenditures for funeral/burial services. For the about-to-be widowed group, after-tax income is found to be positively associated with funeral/burial expenditures. In addition, households residing in rural areas spend more than households living in urban areas.

The estimates in Table 4 suggest that income and prices (as approximated by region of residence, urban/rural location, and presence/absence of health insurance) play an important role in health and funeral/burial expenditures. In addition, life course factors (as approximated by age, ethnicity, family size, employment status, and interview year) are also strongly associated with expenditure totals.

\section{DISCUSSION AND CONCLUSIONS}

The discussion of this study's results must be prefaced with one caveat. Readers should be reminded that the CE data on medical care are collected in a net outlay format that likely leads to substantial underestimation of out-of-pocket medical care expenditures around the time of death. This should lead to an underestimation of about-to-be-widowed households' health care expenditures and make our combined expenditure estimates conservative.

Our estimates reveal that rising health care and funeral/burial expenditures, when combined, constitute a rather high income share for the typical about-to-be-widowed household. Prior research by Zick and Holden (2000), using Survey of Income and Program Participation data, found that household wealth holdings in the period prior to a spouse's death are typi- 
cally modest. Specifically, the 10th, 25th, and 50th percentile figures for total financial wealth in their analyses were $\$ 0, \$ 531$, and $\$ 13,597$, respectively (all in 1996 dollars). If these households with low financial wealth holdings are also facing an average of $\$ 5,099$ in medical and funeral/ burial expenses (Table 1), then their post-widowhood economic position is likely to be even more precarious.

Recall that the median income share of out-of-pocket medical expenditures for about-to-be-widowed households reported in Table 2 is $9.4 \%$ compared to $8.2 \%$ for their continuously married counterparts. In contrast, the corresponding median figures for funeral/burial income shares are $25.0 \%$ and $0.0 \%$. This suggests that funeral and burial expenses may be playing a particularly critical role in exacerbating post-widowhood declines in economic well-being. ${ }^{8}$ It has long been recognized that funeral/ burial expenses can be substantial. Moreover, when someone dies, the surviving spouse is typically confronted with making a number of choices regarding funeral/burial arrangements in a very short period of time. The surviving spouses often know very little about this market, and they typically do very little comparison shopping despite the fact that this market contains substantial variation in the range of services/products offered and their associated prices. Purchase decisions are generally made quickly and after very little, if any, comparison shopping.

In an attempt to help consumers make more informed choices in the burial/funeral markets, the Federal Trade Commission (FTC) adopted the Funeral Rule in 1984 (Federal Trade Commission 2002). This rule, enforced by the FTC, requires that funeral providers give an itemized, written price list of their various services and products to consumers. This price list must note if a state law requires that certain services or products be purchased. The Funeral Rule also requires that a funeral provider not charge a fee for handling a casket purchased elsewhere and that, if they offer cremation services, they must also offer a range of cremation containers.

While the Funeral Rule attempts to ensure that consumers have access to information and a range of products, the extent to which it has reduced consumers' expenditures on funerals and burials is unclear. Davis and Knestout (1997) report that consolidation within the funeral industry may be increasing costs and reducing price variation, while an American Association of Retired Persons (2000) survey found "widespread noncompliance by the industry with the 1984 Funeral Rule."

What can consumer educators do to help families make more informed choices about funeral and burial arrangements, which in turn could help 
insure greater post-widowhood economic stability for the surviving spouse? Encouraging planning while individuals are still healthy would appear to be the key. Such planning should begin with family discussions about what type of funeral and what type of burial arrangements each person wants. Next, couples should engage in comparison shopping. Time spent assessing the range of products and services available along with their associated prices is likely to reduce households' overall expenditures on funerals/burials. Moreover, if decisions are made after thoughtful discussion and without time and emotional pressures, then it is also more likely that consumer preferences will be honored at the time of the death.

It may also be that consumers could reduce their end-of-life expenditures by making better choices in the health insurance market-particularly if families could capitalize on insurance premium savings over an extended time period. But health insurance options are often tied to employment. And if a person is age 65 or older and eligible for Medicare, his or her options for medigap policies will be constrained by law to ten standardized plans. These constraints may translate into less price dispersion and fewer gains from consumer search.

More generally, consumer educators should be encouraging couples to talk about end-of-life expenditures as part of their financial and estate planning activities. Our analyses show that when health and funeral/ burial expenditures near the time of a spouse's death are combined, they typically account for a large share of the household's current income. Advance planning may reduce this immediate economic burden and its longer-term financial consequences for the surviving spouse. Choices regarding health insurance coverage, medigap insurance, and long-term care insurance all have implications for the out-of-pocket medical expenses one will face in the months or years prior to a death. Likewise, advance planning with regard to funerals and burial arrangements - and the life insurance that might be available to cover these costs - can reduce the potential economic burden faced by a newly widowed spouse. The absence of good advance planning in these two domains may be unintentionally increasing the economic vulnerability of widowed individuals.

\section{ENDNOTES}

1. Initially, we also included gifts to charities and gifts to others outside of the consumer unit as two additional expenditure categories. But preliminary analyses (available from the authors upon request) revealed no differences in expenditures on such gifts and thus, for reasons of parsimony, these analyses were deleted from the final paper. 
2. Whether "finalized arrangements" means that payments were made in advance or simply that services/products had been selected is unclear.

3. We first divide the sample into 10 different 5 -year age groups. Those age 85 and older form the last group. Then we compute the frequency distributions of the age of the reference spouse for the continuously married group and the about-to-be-widowed group separately. For example, $4.11 \%$ of the about-to-be-widowed group is in the age 85 and over group, while only $0.66 \%$ of the continuously married group is in that group. Thus, the $\mathrm{CE}$ weights (converted from whole weights to fractional weights for the purpose of SAS programming) for those 85 and over in the continuously married group are multiplied by $4.11 / 0.66$. The new weights are the age-adjusted weights. Note that such a weight adjustment implies that our estimates are not to be interpreted as descriptive population estimates but are to be used for comparison purpose only.

4. Note this only covers nursing home expenditures paid by members of the CU for either current $\mathrm{CU}$ members (who by definition must not be in nursing homes at the time of the interview) or as a gift to someone outside the CU. Statistics show that only about $17 \%$ of nursing home residents were married in 1997 (Gabrel 2000). Thus, nursing home expenditures estimated using our sample are by no means reflective of the overall cost of nursing home care for the nursing home population.

5. Ideally, the multivariate descriptive analyses should also control for the reference spouse's health status. Intuitively, it would seem reasonable to argue that individuals in poor health are more likely than individuals in good health to: (a) have made funeral and burial arrangements well in advance of their deaths, and (b) spend more on health care in the months prior to their deaths. This means that medical expenditures will typically be higher and funeral and burial expenditures should typically be lower if an individual is in poor health compared to an otherwise similar individual whose health is good. While we believe this to be an important descriptive covariate, health status information is not available in the CE data and thus we cannot control for it in our analyses.

6. Lower expenditures on dental care among the about-to-be-widowed group is not that surprising in that family members may delay obtaining dental care when they are dealing with a terminal illness. In contrast, significantly lower health insurance expenditures may reflect a more complicated relationship. We know that individuals with lower incomes face higher mortality risks (Daley, Duncan, Kaplan, and Lynch 1998; McDonough, Duncan, Williams, and House 1997) and thus they are more likely to be in the group of about-to-be-widowed households. Lower income individuals are also less likely to have health insurance available through an employer, or, if they are age 65 or older, they are less likely to have health insurance coverage beyond basic Medicare. Therefore, the relatively lower expenditures on health insurance among the about-to-be widowed are consistent with their more limited incomes.

7. For the about-to-be widowed group, the sample size is small at 137 . Thus, there is a good chance for Type II error, where one accepts the null hypothesis while the alternative hypothesis is true. In this study, even with this sample size, we are able to reject the null hypothesis that there is no difference between the two groups in their expenditures on health care and funeral/burial. Thus the issue of small sample size/low power does not hinder us from achieving our objectives.

8. As noted earlier, while pre-widowhood health care expenses may also contribute to the postwidowhood decline in economic well-being, the way in which out-of-pocket health care expenditure data are collected in the CE Survey prevents us from gaining a confident assessment of what role such expenditures play.

\section{REFERENCES}

Acs, G. and J. Sabelhaus. 1995. Trends in Out-of-Pocket Spending on Health Care, 1980-92. Monthly Labor Review, 118 (12): 35-45.

American Association of Retired Persons. 2002. Funeral Arrangements and Memorial Services. http://www.aarp.org/griefandloss/articles/73_a.html. 
2000. AARP Asks Congress to Focus on Practices of the Funeral Industry. http://www .aarp.org/press/testimony/2000/s041000.html.

Arias, Elizabeth. 2002. United States Life Tables, 2000. National Vital Statistics Reports, 51 (3). http://www.cdc.gov/nchs/data/nvsr/nvsr51/nvsr51_03.pdf.

Bengtson, Vern L. and Katherine R. Allen. 1993. The Life Course Perspective Applied to Families Over Time. In Sourcebook of Family Theories and Methods: A Contextual Approach, edited by Pauline G. Boss, William J. Doherty, Ralph LaRossa, Walter R. Schumm, and Suzanne K. Steinmetz (pp. 469-504). New York: Plenum Press.

Bern-Klug, Mercedes, Stanley DeViney, and David J. Ekerdt. 2001. Variations in Funeral-Related Costs of Older People and the Role of Preneed Funeral Contracts. Omega: Journal of Death and Dying, 41 (1): 23-38.

Bern-Klug, Mercedes, David J. Ekerdt, and Deborah Schild Wilkinson. 1999. What Families Know About Funeral-Related Costs: Implications for Social Work Practice. Health \& Social Work, 24 (2): $128-137$.

Bound, John, Greg J. Duncan, Deborah S. Laren, and Lewis Oleinick. 1991. Poverty Dynamics in Widowhood. Journals of Gerontology: Social Sciences, 46: S115-S124.

Cutler, David M. and Ellen Meara. 1998. The Medical Costs of the Young and Old: A Forty-Year Perspective. In Frontiers in the Economics of Aging, edited by David A. Wise (pp. 215-274). Chicago: University of Chicago Press.

Davis, Kristin and Brian Knestout. 1997. Paying for the Funeral. Kiplinger's Personal Finance Magazine, 51 (5): 66-73.

Daly, Mary C., Greg J. Duncan, George A. Kaplan, and John W. Lynch. 1998. Macro-to-Micro Links in the Relation Between Income Inequality and Mortality. Milbank Quarterly, 76: 315-339.

Fan, Jessie X. 1997. Expenditure Patterns of Asian Americans: Evidence from the U.S. Consumer Expenditure Survey 1980-1992. Family and Consumer Sciences Research Journal, 25 (4):339-368.

Federal Trade Commission. 2002. Funerals: A Consumer's Guide. http://www.ftc.gov/bcp/online/ pubs/services/funeral.htm.

Gabrel, Gelia S. 2000. Characteristics of Elderly Nursing Home Current Residents and Discharges: Data from the 1997 National Nursing Home Survey. Advance Data, No. 312 (April 25): 1-9. http://www.cdc.gov/nchs/data/ad/ad312.pdf.

Garber, Alan M., Thomas E. MaCurdy, and Mark L. McClellan. 1998. Medical Care at the End of Life: Disease, Treatment Patterns, and Costs. NBER Working Paper No. 6748.

Garner, Thesia I. and Laura A. Blanciforti. 1994. Household Income Reporting: An Analysis of U.S. Consumer Expenditure Data. Journal of Official Statistics, 10 (1): 69-71.

Greene, William H. 1997. Econometric Analysis. Upper Saddle River, NJ: Prentice Hall.

Hitschler, Pamela B. 1993. Spending by Older Consumers: 1980 and 1990 Compared. Monthly Labor Review, May: 3-13.

Holden, Karen C., Richard V. Burkhauser, and Daniel J. Feaster. 1988. The Timing of Falls into Poverty After Retirement and Widowhood. Demography, 25: 405-414.

Levinsky, N.G., W. Yu, A. Ash, M. Moskowitz, G. Gazelle, O. Saynina, and E.J. Emanuel. 2001. Influence of Age on Medicare Expenditures and Medical Care in the Last Year of Life. Journal of the American Medical Association, 286: 1349-1355.

Long, Stephen H., James O. Gibbs, Jay P. Crozier, David I. Cooper Jr., John F. Newman Jr., and Arne M. Larsen. 1984. Medical Expenditures of Terminal Cancer Patients During the Last Year of Life. Inquiry, 21: 315-327.

Lubitz, James D. and Gerald F. Riley. 1993. Trends in Medicare Payments in the Last Year of Life. The New England Journal of Medicine, 328 (15): 1092-1096.

Maddala, G.S. 1983. Limited-Dependent and Qualitative Variables in Econometrics. Cambridge, UK: Cambridge University Press.

McDonough, Peggy, Greg J. Duncan, David Williams, and James House. 1997. Income Dynamics and Adult Mortality in the United States, 1972 Through 1989. American Journal of Public Health, 87: $1476-1483$. 
McGarry, Kathleen and Robert F. Schoeni. 2001. Widow Poverty and Out-of-Pocket Medical Expenditures at the End of Life. Paper presented at the Population Association of America's Annual Conference, Atlanta, GA, May 2002.

Mueller, Curt, Claudia Schur, and Joan O'Connell. 1997. Prescription Drug Spending: The Impact of Age and Chronic Disease Status. American Journal of Public Health, 87 (10): 1626-1629.

National Center for Health Statistics. 2002. U.S. Life Tables, 2000. http://www.cdc.gov/nchs/data/ hus/tables/2003/03hus027.pdf.

National Economic Council Interagency Working Group on Social Security. 1998. Women and Retirement Security. Report.

National Funeral Directors Association. 2001. Funeral Price Information. http://www.nfda.org/ resources $/ 2001$ gpl.html.

Rubin, Rose M. and Kenneth Koelln. 1993. Determinants of Household Out-of-Pocket Health Expenditures. Social Science Quarterly, 74 (4): 721-735.

U.S. Bureau of Labor Statistics and the Department of Labor. 1980-2000. Consumer Expenditure Survey. Ann Arbor, MI: Inter-University Consortium for Political and Social Research.

U.S. Bureau of the Census. 1998. Statistical Abstract of the United States. 118th ed. Table 169. Washington, $\mathrm{DC}$.

Weir, David R. and Robert J. Willis. 2000. Prospects for Widow Poverty. In Forecasting Retirement Needs and Retirement Wealth, edited by Olivia S. Mitchell, P. Brett Hammond, and Anna M. Rappaport (pp. 208-234). Philadelphia: University of Pennsylvania Press.

Zick, Cathleen D., Jessie X. Fan, and Kuo-Liang Chang. 2004. Impending Widowhood and Spending on Health Care. Social Sciences Research Journal, 33. Forthcoming.

Zick, Cathleen D. and Karen C. Holden. 2000. An Assessment of the Wealth Holdings of Recent Widows. Journals of Gerontology: Social Sciences, 55: S90-\$97.

Zick, Cathleen D. and Ken R. Smith. 1991. Patterns of Economic Change Surrounding the Death of a Spouse. Journals of Gerontology: Social Sciences, 46: S310-S320. 
Copyright of Journal of Consumer Affairs is the property of University of Wisconsin Press and its content may not be copied or emailed to multiple sites or posted to a listserv without the copyright holder's express written permission. However, users may print, download, or email articles for individual use. 